\title{
PENGARUH GINI RATIO, PDRB PERKAPITA DAN TINGKAT INFLASI TERHADAP TINGKAT KEMISKINAN DI PROVINSI SUMATERA UTARA
}

\author{
Hastina Febriaty \\ Nurwani \\ Fakultas Ekonomi dan Bisnis Universitas Muhammadiyah Sumatera Utara \\ Email: hastinafebriaty@umsu.ac.id
}

\begin{abstract}
Poverty is a living condition that is in shortage experienced by a person or household so as not being able to meet the minimal or decent needs for his life. And poverty is a social problem that is always present in the midst of society.

In this research discusses the influence of Gini Ratio, Per Capita GDP and Inflation Rate to Poverty Level in North Sumatera Province. The purpose of this research is to know the influence of Gini Ratio, PDRB / Kapita and Inflation rate to poverty level in North Sumatera province, partially and simultaneously, and the dominant influence variable to poverty level in North Sumatera Province. Sources of data used are secondary data taken from the Central Bureau of Statistics and Bank of Indonesia from 2001 to 2016.Teknik analysis used in this research is multiple linear regression analysis using e-views program 8.1 and perform testing classical assumptions and using hypothesis testing simultaneously $(F)$ and partial $(t)$.

The results showed that partially Gini Ratio and PDRB / Kapita have negative and significant effect to poverty level in North Sumatera Province while inflation rate have positive and insignificant effect to poverty level in North Sumatera Province simultaneously Gini Ratio, PDRB Perkapita and inflation rate have significant effect of poverty level in North Sumatera Province.
\end{abstract}

Keywords: Gini Ratio, Per Capita GDP, Inflation Rate and Poverty Level.

\section{PENDAHULUAN}

P

engentasan kemiskinan menjadi salah satu dari Tujuan Pembangunan Milenium atau Millennium Development Goals (MDGs) yaitu menanggulangi kemiskinan dan kelaparan, yang merupakan hasil kesepakatan kepala negara dan perwakilan dari 189 negara Perserikatan Bangsa-bangsa (PBB) yang mulai dijalankan pada September 2000. Salah satu target dari tujuan tersebut adalah menurunkan QE Journal | Vol.06 - No. 03 December 2017 - 173 
persentase penduduk yang pendapatannya kurang dari 1 dolar sehari sebanyak 50 persen tahun 1990-2015 dengan indikator proporsi penduduk yang hidup dibawah garis kemiskinan nasional.

Penyebab kemiskinan bermuara pada teori lingkaran kemiskinan (vicious circke of poverty) dari Nurkse 1953. Yang dimaksud lingkaran kemiskinan adalah suatu rangkaian kekuatan yang saling mempengaruhi suatu keadaaan dimana suatu negara akan tetap miskin dan akan banyak mengalami kesukaran untuk mencapai tingkat pembangunan yang lebih baik. Adanya keterbelakangan, dan ketertinggalan SDM (yang tercermin oleh rendahnya IPM), ketidaksempurnaan pasar, dan kurangnya modal menyebabkan rendahnya produktifitas. Rendahnya produktifitas mengakibatkan rendahnya pendapatan yang mereka terima (yang tercermin oleh rendahnya PDRB per kapita). Rendahnya pendapatan akan berimplikasi pada rendahnya tabungan dan investasi. Rendahnya investasi berakibat pada rendahnya akumulasi modal sehingga proses penciptaan lapangan kerja rendah (tercemin oleh tingginya jumlah pengangguran). Rendahnya akumulasi modal disebabkan oleh keterbelakangan dan seterusnya

Menurut data BPS Sumatera utara (2015) dari Hasil Survei Sosial Ekonomi Nasional (Susenas) yang dilaksanakan pada bulan Maret 2015 menunjukkan bahwa jumlah penduduk miskin di Provinsi Sumatera Utara sebanyak 1.463 .670 orang atau sebesar 10,53 persen terhadap jumlah total penduduk. Kondisi ini lebih buruk jika dibandingkan dengan kondisi September 2014 yang jumlah penduduk miskinnya sebanyak 1.360.600 orang atau sebesar 9,85 persen. Dengan demikian, ada peningkatan jumlah penduduk miskin sebanyak 103.070 orang serta peningkatan persentase penduduk miskin sebesar 0,68 poin. Bank Dunia menetapkan garis kemiskinan internasional sebesar 1,25 dollar AS per kapita per hari. Artinya, yang dianggap miskin di dunia ini,di negara manapun individu tersebut berada adalah yang memiliki pendapatan kurang dari 1,25 dollar AS per hari. Perkembangan tingkat kemiskinan mulai tahun 1999 sampai dengan tahun 2015, ditunjukkan pada Tabel 1. 
Tabel 1. Jumlah dan Persentase Penduduk Miskin Sumatera Utara

\begin{tabular}{lcc}
\hline $\begin{array}{c}\text { Tahun 1999-2015 } \\
\text { Tahun }\end{array}$ & $\begin{array}{c}\text { Jumlah } \\
\text { (ribu jiwa) }\end{array}$ & $\begin{array}{c}\text { Persentase } \\
\mathbf{( \% )}\end{array}$ \\
\hline Februari 1999 & $\mathbf{( 2 )}$ & $\mathbf{( 3 )}$ \\
Februari 2002 & 1972,7 & 16,74 \\
Februari 2003 & 1883,9 & 15,84 \\
Maret 2004 & 1889,4 & 15,89 \\
Juli 2005 & 1800,1 & 14,93 \\
Mei 2006 & 1840,2 & 14,68 \\
Maret 2007 & 1979,7 & 15,66 \\
Maret 2008 & 1768,4 & 13,90 \\
Maret 2009 & 1613,8 & 12,55 \\
Maret 2010 & 1499,7 & 11,51 \\
Maret 2011 & 1490,9 & 11,31 \\
September 2011 & 1492,2 & 11,33 \\
Maret 2012 & 1436,4 & 10,83 \\
September 2012 & 1425,8 & 10,67 \\
Maret 2013 & 1400,4 & 10,41 \\
September 2013 & 1362,4 & 10,06 \\
Maret 2014 & 1416,4 & 10,39 \\
September 2014 & 1286,7 & 9,38 \\
Maret 2015 & 1360,6 & 9,85 \\
\hline
\end{tabular}

Sumber : Diolah dari data survey sosial ekonomi nasional (Susenas)

Jumlah penduduk miskin Sumatera Utara yang berada di daerah perkotaan pada Maret 2015 sebanyak 699.300 orang dan di daerah perdesaan sebanyak 764.370 orang. Jika dibandingkan dengan penduduk yang tinggal pada masing-masing daerah tersebut, maka persentase penduduk miskin di daerah perkotaan sebesar 10,16 persen, sedangkan di daerah perdesaan sebesar 10,89 persen. Banyaknya angka kemiskinan tentunya disebabkan oleh masalah ekonomi di wilayah ini. Perlambatan, penyesuaian harga BBM serta memburuknya harga komoditas Sumatera Utara yang terus memburuk menjadi faktor utama melonjaknya angka kemiskinan di wilayah ini. Secara keseluruhan memburuknya angka kemiskinan digambarkan dengan penurunan daya beli masyarakat yang sangat rendah. Inflasi yang rendah juga bisa diasumsikan bahwa ada penurunan daya beli masyarakat semakin miskin. 
Dari data yang di uraikan diatas, jika kita melihat kebelakang bahwa kebijakan pemerintah yang selama ini jarang terjadi yaitu melakukan penurunan harga BBM setelah sempat dinaikkan, bisa memunculkan kelegaan serta mengurangi beban ekonomi yang harus ditanggung rakyat. Namun, faktanya kebijakan menurunkan harga BBM itu, tidak terlalu dirasakan rakyat manfaatnya. Sebab, jauh sebelumnya harga-harga kebutuhan sehari-hari (sembako) serta harga di sektor lainnya, sudah mengalami kenaikan atau terjadi inflasi dan sukar diharapkan akan mengalami penurunan. Situasi ini agaknya ikut mempengaruhi kehidupan masyarakat, khususnya di Sumatera Utara, yang belum bisa bangkit dari keterpurukan, akibat lemahnya pertumbuhan ekonomi serta tidak adanya peningkatan ketersediaan lapangan pekerjaan.

Di sisi lain, adanya permasalahan kemiskinan dan ketidakmerataan pendapatan juga akan menghambat laju pertumbuhan ekonomi itu sendiri. Selain itu, kemiskinan dan ketidakmerataan pendapatan juga akan memberikan dampak instabilitas sosial, ketidakpastian, dan tragedi kemanusiaan seperti kelaparan, tingkat kesehatan yang rendah dan gizi buruk. Bila keadaan tersebut terus berlanjut pada akhirnya akan mengganggu stabilitas ekonomi makro dan kelangsungan pemerintahan yang ada.

Masalah kependudukan Indonesia dalam hal kualitas adalah masalah kependudukan dalam hal mutu kehidupan dan kemampuan sumber daya manusianya. Di Indonesia, masalah kualitas penduduk yang terjadi, antara lain, dipengaruhi oleh masih rendahnya tingkat pendidikan dan kualitas sumber daya manusia, rendahnya taraf kesehatan sehingga kesemuanya itu pada akhirnya mengarah pada rendahnya pendapatan perkapita masyarakatnya

Tingkat ketimpangan penduduk di Sumatera Utara yang diukur berdasarkan gini ratio pada September 2016 memang mencapai 0,312. Namun Sumut masih mencatatkan gini ratio di atas 0,300 . Nilai gini ratio berkisar antara 0-1. Semakin mendekati angka 1, berarti gini ratio menunjukkan ketimpangan yang semakin tinggi. 
Tabel 2 Gini Ratio Provinsi Sumatera Utara

\section{$\mathrm{Kab} / \quad$ Gini Rasio

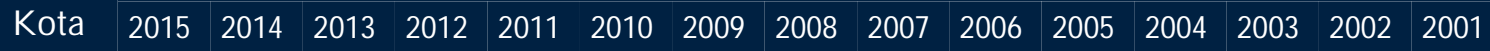 \\ Sumat \\ $\begin{array}{llllllllllllllll}\text { era } & 0.34 & 0.31 & 0.33 & 0.34 & 0.32 & 0.32 & 0.32 & 0.32 & 0.28 & 0.31 & 0.34 & 0.28 & 0.29 & 0.29 & 0.27\end{array}$ \\ Utara \\ Sumber : BPS Sumatera Utara}

Dari tabel diatas dapat dilihat angka tingkat ketimpangan distribusi pendapatan Sumatera

Utara berdasarkan Indeks Gini Ratio setiap tahun mengalami peningkatan sebesar 0,34 pada tahun 2015 dibandingkan tahun 2014 sebesar 0,31.

Ketimpangan memiliki dampak positif maupun dampak negatif. Dampak positif dari adanya ketimpangan adalah dapat mendorong wilayah lain yang kurang maju untuk dapat bersaing dan meningkatkan pertumbuhannya guna meningkatkan kesejahteraannya. Sedangkan dampak negatif dari ketimpangan yang ekstrim antaralain inefisiensi ekonomi, melemahkan stabilitas sosial dan solidaritas, serta ketimpangan yang tinggi pada umumnya dipandang tidak adil (Todaro,2011). Tidak meratanya distribusi pendapatan memicu terjadinya ketimpangan pendapatan yang merupakan awal dari munculnya masalah kemiskinan. Membiarkan kedua masalah tersebut berlarut-larut akan semakin memperparah keadaan, dan tidak jarang menimbulkan konsekuensi negatif terhadap kondisi sosisal dan politik.

Dari permasalahan diatas, maka tujuan dari penelitian ini adalah untuk mengetahui pengaruh Gini Ratio, PDRB/Kapita dan Tingkat Inflasi terhadap Tingkat Kemiskinan di Provinsi Sumatera Utara secara parsial dan simultan

\section{METODE PENELITIAN}

Penelitian ini menggunakan data sekunder dengan jenis data runtun waktu (time series) selama kurun waktu 2001 sampai dengan 2016. Data yang digunakan dalam penelitian ini adalah data kuantitatif yang dapat berupa kuantitas, nomor, pengukuran dan statistik (Mustari,2012:37). Data yang dipergunakan dalam penelitian adalah data sekunder. Menurut Sugiyono (2008:129) data sekunder adalah data yang diperoleh dari sumber lain atau 
lewat dokumen. Data yang digunakan dalam penelitian ini diambil sumber Badan Pusat Statistik (BPS) yang dipublikasi dari laporan-laporan tahunan dan Bank Indonesia (BI) dari Kajian Ekonomi Regional khusus Sumatera Utara.

Metode pengumpulan data dalam penelitian ini adalah metode observasi non partisipan yaitu teknik pengumpulan data dimana peneliti tidak terlibat langsung dan hanya sebagai pengamat independen (Sugiyono,2008) Penelitian ini menggunakan model teknik analisis data regresi linear berganda. Penelitian ini diuji dengan menggunakan uji simultan (F-test) dan uji parsial (t-test) untuk mengetahui pengaruh antar variabel. Adapun fungsi dan persamaan dari regresi linear berganda tersebut adalah sebagai berikut :

$$
\mathrm{TKM}=\mathrm{f}(\mathrm{GR}, \mathrm{PDRB} / \text { Kapita, Inf })
$$

Selanjutnya fungsi di atas dispesifikasi kedalam model estimasi dengan menggunakan model regresi linear berganda, yaitu :

Persamaan regresi linier berganda dapat dirumuskan sebagai berikut:

$$
\mathrm{TKM}=\beta 0+\beta 1 \mathrm{GR}+\beta 2 \mathrm{PDRB} / \text { Kapita }+\beta 3 \text { Inf }+ \text { ei }
$$

Dimana:

TKM : Jumlah penduduk miskin di Provinsi Sumut dalam satuan persen $\beta 0 \quad$ : Intersep

$\beta 1, \beta 2, \beta 3$ : Koefisien regresi

GR : Gini Ratio $0-1.0$ = Pemerataan sempurna, $1=$ ketimpangan sempurna

PDRB/Kapita : Pendapatan Perkapita Regional satuan juta Rupiah

Inf : Tingkat Inflasi dalam persen

ei : term of error

Untuk ketepatan penghitungan sekaligus mengurangi human error, digunakan program komputer yang dibuat khusus untuk membantu pengolahan data statistik, yaitu program Eviews 8.1 dengan tingkat signifikansi pada level of confidence 95 persen atau $\alpha=0.05$.

Uji Asumsi Klasik

Uji asumsi klasik diperlukan untuk dapat melakukan analisis regresi berganda Pengujian tersebut dilakukan untuk menghindari atau 
mengurangi bias atas hasil penelitian yang diperoleh. Pengujian asumsi klasik yang digunakan dalam penelitian ini meliputi uji normalitas, uji multikolinearitas, uji autokorelasi (Erlina, 2011:102)

\section{Uji Hipotesis}

1. Uji Statistik $\mathrm{t}$ pada dasarnya menunjukkan seberapa jauh satu variabel independen secara individual atau parsial dapat menerangkan variasi variabel terikat.

2. Uji Statistik F pada dasarnya menunjukkan apakah semua variabel independen yang dimasukkan dalam model mempunyai pengaruh secara simultan terhadap variabel dependen.

3. Koefisien Determinasi (R2) untuk menentukan apakah model regresi cukup baik digunakan, maka ditetapkan melalui koefisien determinasi. Nilai adjusted R2 dapat naik atau turun apabila satu variabel independen ditambahkan ke dalam model regresi (Ghozali,2006:87).

\section{HASIL DAN PEMBAHASAN}

\section{Uji Normalitas}

Uji normalitas yang dimaksud dalam asumsi klasik pendekatan OLS adalah (data) residual yang dibentuk model regresi linier terdistribusi normal, bukan variabel bebas ataupun variabel terikatnya. Pengujian terhadap residual terdistribusi normal atau tidak dapat menggunakan Jarque-Bera Test.

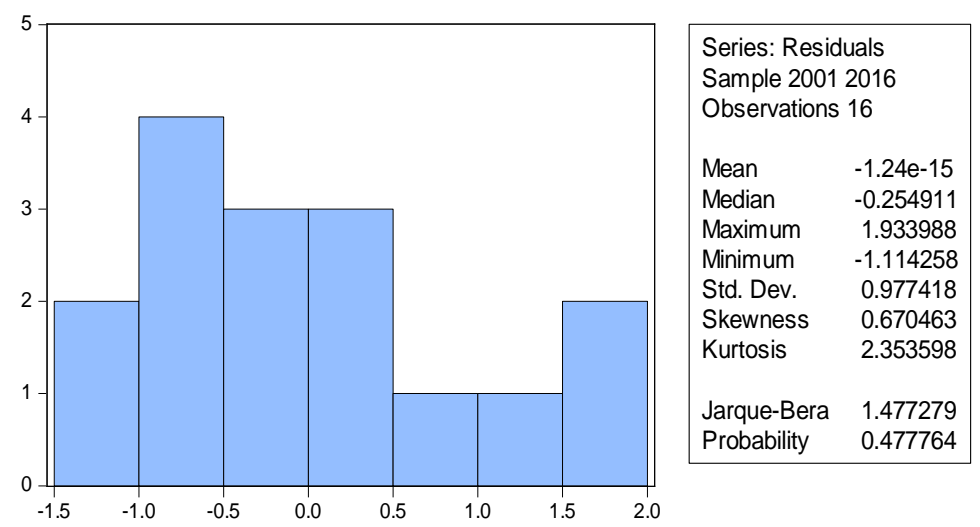

Gambar 2. Uji Normalitas Jarque-Bera Test

Sumber: Data Diolah 
Keputusan terdistribusi normal tidaknya residual secara sederhana dengan membandingkan nilai Probabilitas JB (Jarque-Bera) hitung dengan tingkat alpha 0,05 (5\%). Nilai Prob. JB hitung sebesar 0,477764>0,05 sehingga dapat disimpulkan bahwa residual terdistribusi normal yang artinya asumsi klasik tentang kenormalan telah dipenuhi.

Heterokedastisitas

Heteroskedastisitas terjadi pada saat residual dan nilai prediksi memiliki korelasi atau pola hubungan. Pola hubungan ini tidak hanya sebatas hubungan yang linier, tetapi dalam pola yang berbeda juga dimungkinkan. Oleh karena itu ada beberapa metode uji heteroskedastisitas salah satunya aalah metode Glejser.

Tabel 3. Uji Heterokedastisitas.

Heteroskedasticity Test: Glejser

\begin{tabular}{llll}
\hline F-statistic & 1.295512 & Prob. F(3,12) & 0.3209 \\
Obs*R-squared & 3.914295 & Prob. Chi-Square(3) & 0.2709 \\
Scaled explained SS & 2.173951 & Prob. Chi-Square(3) & 0.5371 \\
\hline
\end{tabular}

Sumber: Data diolah

Keputusan terjadi atau tidaknya heteroskedastisitas pada model regresi linier adalah dengan melihat Nilai Prob. F-statistic (F hitung). Apabila nilai Prob. F hitung lebih besar dari tingkat alpha 0,05 (5\%) maka H0 diterima yang artinya tidak terjadi heteroskedastisitas, sedangkan apabila nilai Prob. F hitung lebih kecil dari tingkat alpha 0,05 (5\%) maka H0 ditolak yang artinya terjadi heteroskedastisitas. Nilai Prob. F hitung sebesar 0,3209 lebih besar dari tingkat alpha 0,05 (5\%) sehingga, berdasarkan uji hipotesis, H0 diterima yang artinya tidak terjadi heteroskedastisitas.

Multikolinearitas

Uji multikolinieritas pada penelitian ini dapat dilihat pada Tabel 4 dibawah ini: 
Tabel 4. Uji Multikolinearitas

\begin{tabular}{|c|c|c|c|}
\hline $\begin{array}{l}\text { Variance Inflation Factors } \\
\text { Date: 10/24/17 Time: 16:40 } \\
\text { Sample: } 20012016 \\
\text { Included observations: } 16\end{array}$ & & & \\
\hline Variable & $\begin{array}{c}\text { Coefficient } \\
\text { Variance }\end{array}$ & $\begin{array}{c}\text { Uncentered } \\
\text { VIF }\end{array}$ & $\begin{array}{c}\text { Centered } \\
\text { VIF }\end{array}$ \\
\hline C & 19.00291 & 254.6063 & NA \\
\hline Gini Ratio & 231.7468 & 301.0887 & 1.493072 \\
\hline PDRB/Kapita & $8.36 \mathrm{E}-10$ & 6.545430 & 1.663352 \\
\hline Tk Inflasi & 0.003667 & 4.277863 & 1.166777 \\
\hline
\end{tabular}

Sumber : Data diolah

Hasil uji multikolinieritas, dapat dilihat pada tabel kolom Centered VIF. Nilai VIF untuk variabel Gini Ratio 1.493072, PDRB/Kapita 1.663352 dan Inflasi 1.166777. Karena nilai VIF dari ketiga variabel tidak ada yang lebih besar dari 10 maka dapat dikatakan tidak terjadi multikolinieritas pada ketiga variabel bebas tersebut. Berdasarkan syarat asumsi klasik regresi linier dengan OLS, maka model regresi linier yang baik adalah yang terbebas dari adanya multikolinieritas. Dengan demikian, model di atas telah terbebas dari adanya multikolinieritas.

$\underline{\text { Autokorelasi }}$

Guna memastikan apakah model regresi linier terbebas dari autokorelasi, dapat menggunakan metode Brusch-Godfrey atau LM (Lagrange Multiplier) Test.

Tabel 5. Uji Autokorelasi

Breusch-Godfrey Serial Correlation LM Test:

\begin{tabular}{llll} 
F-statistic & 0.471707 & Prob. F(2,10) & 0.6371 \\
Obs*R-squared & 1.379333 & Prob. Chi-Square(2) & 0.5017 \\
\hline
\end{tabular}

Sumber: Data diolah

Nilai Prob. $F(2,10)$ sebesar 0,6371 dapat juga disebut sebagai nilai probabilitas $\mathrm{F}$ hitung. Nilai Prob. F hitung lebih besar dari tingkat alpha 0,05 (5\%) sehingga, berdasarkan uji hipotesis, H0 diterima yang artinya QE Journal | Vol.06 - N o. 03 December 2017 - 181 
tidak terjadi autokorelasi. Sebaliknya, apabila nilai Prob. F hitung lebih kecil dari 0,05 maka dapat disimpulkan terjadi autokorelasi.

\section{Hasil Uji Koefisien Determinasi (R-Square)}

Nilai R-Square pada tabel 6 di bawah ini besarnya 0,8503 menunjukkan bahwa proporsi pengaruh variabel gini ratio, PDRB/Kapita dan tingkat inflasi berpengaruh terhadap variabel tingkat kemiskinan sebesar 85.03\%. Artinya gini ratio, PDRB/Kapita dan tingkat inflasi memiliki proporsi pengaruh terhadap tingkat kemiskinan sebesar $85.03 \%$ sedangkan sisanya $14.97 \%(100 \%-85.03 \%)$ dipengaruhi oleh variabel lain yang tidak ada didalam model regresi.

Tabel 6. Hasil Regresi Koefisien Determinasi, Uji t dan Uji f

\begin{tabular}{lclcc}
\hline $\begin{array}{l}\text { Dependent Variable: Tingkat Kemiskinan } \\
\text { Method: Least Squares }\end{array}$ & & \\
Date: $10 / 24 / 17$ Time: 16:32 & & & \\
$\begin{array}{l}\text { Sample: 2001 2016 } \\
\text { Included observations: 16 }\end{array}$ & & & & \\
\hline & Coefficient & Std. Error & t-Statistic & Prob. \\
Variable & & & & \\
& 26.18536 & 4.359233 & 6.006873 & 0.0001 \\
C & -36.92377 & 15.22323 & -2.425488 & 0.0320 \\
Gini Ratio & -0.000126 & $2.89 E-05$ & -4.375138 & 0.0009 \\
PDRB/Kapita & 0.096776 & 0.060556 & 1.598134 & 0.1360 \\
Tk Inflasi & & & & \\
& 0.850331 & Mean dependent var & 12.84500 \\
R-squared & 0.812914 & S.D. dependent var & 2.526476 \\
Adjusted R-squared & 1.092787 & Akaike info criterion & 3.227658 \\
S.E. of regression & 14.33020 & Schwarz criterion & 3.420805 \\
Sum squared resid & -21.82126 & Hannan-Quinn criter. & 3.237548 \\
Log likelihood & 22.72571 & Durbin-Watson stat & 1.561241 \\
F-statistic & 0.000031 & & & \\
Prob(F-statistic) & & &
\end{tabular}

Sumber: Data sekunder diolah

\section{$\underline{\text { Hasil Uji Simultan }(\mathrm{F})}$}

Hasil uji F dapat dilihat pada tabel 6 di atas. Nilai prob. F (Statistic) sebesar 0,000031 lebih kecil dari tingkat signifikansi 0,05 sehingga dapat disimpulkan bahwa model regresi yang diestimasi layak digunakan untuk 
menjelaskan pengaruh gini ratio, PDRB/Kapita dan tingkat inflasi terhadap tingkat kemiskinan di provinsi Sumatera Utara. Itu artinya hipotesis $\mathrm{H} 4$ dapat diterima.

\section{Hasil Uji Parsial (t)}

\section{a. Gini Ratio}

Dari hasil regresi, nilai koefisien untuk variabel Gini Ratio adalah 36.92377 dimana variabel tersebut berpengaruh signifikan terhadap tingkat kemiskinan di Provinsi Sumatera Utara. Hal ini ditunjukkan dengan nilai $\mathbf{t}_{\text {hitung }}=-2.425488$ dan nilai probability sebesar 0.0320 (di bawah $\alpha=5 \%$ atau 0.05 ). Hal ini menunjukkan bahwa hubungan antara gini ratio dengan kemiskinan adalah negatif dan signifikan. Sehingga dapat dikatakan bahwa jika Gini Ratio mengalami penurunan maka tingkat kemiskinan akan mengalami kenaikan, maka hipotesis (H1) Diterima.

\section{b. PDRB/Kapita}

Dari hasil regresi, nilai koefisien untuk variabel PDRB/Kapita adalah 0.000126 dimana variabel tersebut berpengaruh signifikan terhadap tingat kemsikinan di Provinsi Sumatera Utara. Hal ini ditunjukkan dengan nilai $\mathbf{t}_{\text {hitung }}=-4.375138$ dan nilai probability sebesar 0.0009 (di bawah $\alpha=5 \%$ atau 0.05). Hal ini menunjukkan bahwa hubungan antara PDRB/Kapita dengan tingkat kemiskinan adalah negatif dan signifikan. Sehingga dapat dikatakan bahwa jika nilai PDRB/Kapita mengalami penurunan maka tingkat kemiskinan akan mengalami kenaikan. maka hipotesis (H2) diterima.

\section{c. Tingkat Inflasi}

Dari hasil regresi, nilai koefisien untuk variabel inflasi adalah 0.096776 dimana variabel tersebut berpengaruh tidak signifikan terhadap tingkat kemiskinan di Provinsi Sumatera Utara. Hal ini ditunjukkan dengan nilai $\mathbf{t}_{\text {hitung }}=1.598134$ dan nilai probability sebesar 0.1360 (di atas $\alpha=5 \%$ atau 0.05). Hal ini menunjukkan bahwa hubungan antara tingkat inflasi dengan tingkat kemiskinan adalah positif dan tidak signifikan. Sehingga dapat dikatakan bahwa jika tingkat inflasi naik maka tingkat kemiskinan akan mengalami kenaikan, maka hipotesis (H3) ditolak 
Analisis Regresi Linear Berganda

TKM $=26.18536--36.92377$ GR --0.000126 PDRB Kapita +0.096776 inf $+\mu$

\section{SIMPULAN}

Hasil pengujian hipotesis yang pertama menunjukkan bahwa Gini Ratio berpengaruh negatif dan signifikan terhadap Tingkat Kemiskinan di Provinsi Sumatera Utara hal ini tidak sejalan dengan penelitian (Pendi, dkk, 2014) bahwa Nilai elastisitas netto kemiskinan terhadap pertumbuhan ekonomi $(\lambda)$ sebesar 0,958 . ketimpangan pendapatan yang terjadi bukan hanya mengurangi keefektifan dari pengaruh pertumbuhan ekonomi, namun malah menaikan angka kemiskinan.Pertumbuhan ekonomi yang terjadi pada periode tersebut mengurangi ketimpangan pendapatan, namun pengurangan ketimpangan pendapatan tersebut justru meningkatkan kemiskinan. Kemiskinan seharusnya turun sebesar 0,122 persen jika ada pertumbuhan ekonomi sebesar 1 persen, namun karena adanya efek ketimpangan pendapatan, maka kemiskinan naik menjadi sebesar 0,958 persen. Hal ini mengindikasikan bahwa efek peningkatan ketimpangan pendapatan yang terjadi bukan hanya mengurangi keefektifan dari pengaruh pertumbuhan ekonomi, namun malah menaikan angka kemiskinan. Pertumbuhan ekonomi yang terjadi pada periode tersebut mengurangi ketimpangan pendapatan, namun pengurangan ketimpangan pendapatan disebabkan karena ketimpangan distribusi pendapatan terhadap kemiskinan dipengaruhi oleh adanya peningkatan jumlah penduduk. Pertambahan penduduk cenderung berdampak negatif terhadap penduduk miskin, terutama bagi mereka yang sangat miskin. Sebagian besar keluarga miskin memiliki jumlah anggota keluarga yang banyak sehingga kondisi perekonomian mereka yang berada di garis kemiskinan semakin memburuk seiring dengan memburuknya ketimpangan pendapatan atau kesejahteraan sehingga salah satu penyebab dari kemiskinan adalah adanya ketidaksamaan pola kepemilikan sumber daya yang selanjutnya akan menimbulkan distribusi pendapatan yang timpang (Todaro,2000).

Hasil pengujian hipotesis kedua menunjukkan bahwa PDRB/kapita berpengaruh negatif dan signifikan terhadap Kemiskinan di Provinsi Sumatera Utara sehingga hipotesis dalam penelitian ini terjawab. Hasil penelitian ini juga sejalan dengan dengan penelitian Chandra dkk (2010) 
yang menunjukkan pendapatan perkapita berpengaruh negatif terhadap kemiskinan di Jawa Tengah (2003-2010). Pendapatan Perkapita merupakan salah satu ukuran kemakmuran bagi tiap daerah. Semakin tinggi pendapatan tersebut maka semakin tinggi daya beli penduduk, dan daya beli yang bertambah ini akan meningkatkan kesehjateraan masyarakat (Sukirno, 2006). Hal ini sesuai dengan penelitian Wiguna (2013), pada penelitian tersebut mengindikasikan bahwa apabila PDRB per kapita meningkat maka penduduk di wilayah tersebut semakin sejahtera atau apabila PDRB per kapita meningkat, maka tingkat kemiskinan pun akan berkurang. Serta, hal lain yang akan mendukung laju pertumbuhan ekonomi yang lebih tinggi adalah dengan melakukan pengurangan kemiskinan dengan lebih cepat dan tepat (Rusdarti, 2013). Penelitian ini juga sesuai dengan penelitian yang dilakukan oleh Whisnu (2011), pada penelitian ini menyatakan semakin tinggi PDRB, maka tingkat kemiskinan akan berkurang.

Hasil dari pengujian hipotesis ketiga ini menyatakan bahwa inflasi berpengaruh positif terhadap kemisikinan di Provinsi Sumatera Utara. Artinya jika inflasi naik maka kemiskinan juga akan bertambah dikarenakan inflasi yang ditandai dengan kenaikan harga tersebut akan menyebabkan penduduk yang miskin akan mengurangi tingkat konsumsinya karena nilai uang yang mereka pegang (pendapatan riil) juga semakin kecil sehingga menurunkan tingkat konsumsi mereka dan menyebabkan jumlah penduduk miskin akan bertambah. Hasil penelitian ini sejalan dengan penelitian Imelia (2012) yang menyatakan bahwa Variabel inflasi berpengaruh positif tetapi tidak signifikan terhadap kemiskinan di Provinsi Jambi Menurutnya tidak signifikannya variabel inflasi tersebut dikarenakan perlu adanya penelitian lebih lanjut dengan menggunakan model analisis lain. Pengukuran laju inflasi yang terjadi pada perekonomian propinsi Jambi yang dilakukan oleh BPS propinsi Jambi bukan hanya didasarkan pada indeks harga konsumen (IHK) kota Jambi tetapi dikota-kota lainnya dalam wilayah propinsi Jambi.

Hasil dari uji simultan menyatakan bahwa Gini Ratio, PDRB/Kapita dan Tingkat Inflasi berpengaruh signifikan terhadap Tingkat Kemiskinan di Provinsi Sumatera Utara. Hal ini menunjukkan bahwa variabel-variabel tersebut dapat mempengaruhi perubahan tingkat kemiskinan ke arah 
yang lebih baik atau justru ke arah yang lebih buruk yang dapat berdampak kepada perekonomian khususnya di Provinsi Sumatera Utara.

\section{DAFTAR PUSTAKA}

Boediono. 2008. Ekonomi Makro. Edisi Keempat. Fakultas Ekonomi UGM. Yogyakarta

Badan Pusat Statistik Sumatera Utara . 2015. Sumut Dalam Angka. Sumut

Chandra, A. 2010. Keterkaitan Pertumbuhan Ekonomi dan Pendapatan Per Kapita terhadap Kemiskinan di Jawa Tengah Tahun 2003-2010. Jurnal Media Ekonomi \& Teknologi Informasi Vol 20. No.2

Edi Suharto, Kemiskinan dan Perlindungan Sosial di Indonesia: Menggagas Model Jaminan Sosial Universal Bidang Kesehatan. (Bandung: CV Alfabeta, 2009), hal 17

Erlina. 2011. Metode Penelitian.USU Press. Medan

Ghozali, Imam. 2005. Aplikasi Analisis Multivariate dengan program SPSS, Badan Penerbit Universitas Diponegoro, Semarang.

Hadi Sasana. 2001. "Produk Domestik Bruto dan Strukturnya". Diklat Teknis Perencanaan Pembangunan Ekonomi Daerah Propinsi Jawa Tengah, Oktober-November. Semarang.

Imelia, 2012. Pengaruh Inflasi Terhadap Kemiskinan di Provinsi Jambi. Jurnal Paradigma Ekonomika Universitas Jambi. Vol.1 No.5 April 2012

Kuncoro, Mudrajad. 2004. Otonomi dan Pembangunan Daerah. Jakarta. Penerbit Erlangga.

Mustari, Mohamad. 2012. Pengantar Metode Penelitian. LaksBang. Surabaya.

Nilsen, R.Sigurd. 2007. Poverty in America: Consequences For Individual and The Economy Paper Presented for United States Government Accountabillity Office. Amerika Serikat: GAO.

Norton, Seth W. 2002. Economic Growth and Provery: In Search of Trickle Down. Cato Journal, 22(2), pp: 263-275. 
Rusdarti, Lesta K. 2013. Faktor-Faktor Yang Mempengaruhi Tingkat Kemiskinan di Provinsi Jawa Tengah. Jurnal Economia Volume 9 Nomor 1, Universitas negeri Semarang

Sugiyono. 2008. Metode Penelitian Bisnis. Bandung:Alfabeta.

Sukirno, 2006. Ekonomi Pembangunan: Proses Masalah dan Dasar Kebijakan. Kencana Jakarta

Sukirno, Sadono. 2004 "Teori Pengantar Makro Ekonomi", PT.Raja Grafindo Persada, Jakarta

Sukirno, Sadono. 2000. Makro Ekonomi Teori Pengantar. PT. Raja Grafindo Persada. Jakarta.

Suharto, Edi. 2009. Kemiskinan dan Perlindungan Sosial di Indonesia. Alfabeta: Bandung.

Todaro, Michael P. and Smith, Stephen C. 2011. Economic Development. Eleventh Edition.

United States: Addison Wesley.

Thamrin Simanjuntak. 2001, Analisis Potensi Pendapatan Asli Daerah, Bunga Rampai Manajemen Keuangan Daerah. Yogyakarta: Penerbit UPP AMP YKPN.

Wiguna, Van Indra, 2013.Analisis Pengaruh PDRB, Pendidikan dan Pengangguran Terhadap Kemiskinan di Provinsi Jawa Tengah Tahun 2005-2010. Jurnal Ilmu Ekonomi, Fakultas Ekonomi dan Bisnis Universitas Brawijaya Malang.

Wishnu, Bagio Mukadir, 2011. Analisis Pengaruh Jumlah Penduduk, PDRB, IPM, Pengangguran Terhadap Tingkat Kemiskinan di Kabupaten/Kota Jawa Tengah. Jurnal Ilmu Ekonomi dan Studi Pembangunan. Fakultas Ekonomi Universitas Diponegoro. 